\title{
Seres imaginarios y motivos de la literatura oral en Mitos, leyendas y cuentos peruanos de José María Arguedas y Francisco Izquierdo Ríos
}

\author{
Imaginary Beings and Motifs of Oral Literature in Mitos, \\ leyendas y cuentos peruanos by José María Arguedas and \\ Francisco Izquierdo Ríos
}

\author{
Nécker SAlaZAR MeJía \\ (Universidad Nacional Federico Villarreal, Perú) \\ nsalazar@unfv.edu.pe \\ ORCID ID: 0000-0003-0691-4359
}

\begin{abstract}
This work studies oral literature in Mitos, leyendas y cuentos peruanos (1947), an important compilation made by José María Arguedas and Francisco Izquierdo Ríos. The book is made up of stories from the coast, the mountains and the jungle, and it is a benchmark ofbasic knowledge for the oral memory of the peoples of Peru. By reading a selection of them, the main themes and motifs of oral literature will be examined, and the mythical and magical dimension of the characters and imaginary beings of the Andean and Amazonian universe will be studied. The research highlights the predominant theme in the stories, as well as the role of its protagonists in the represented world. From our point of view, the compilation by Arguedas and Izquierdo Ríos, which is an invaluable source for the study and the investigation of the folk narrative, is a veritable encyclopedia of oral literature and shows the enormous literary and cultural wealth of Peru.
\end{abstract}

KEYWORDS: oral literature, traditional motifs, Andean and Amazonian mythology, imaginary beings
RESUMEN: El presente artículo estudia la literatura oral en Mitos, leyendas y cuentos peruanos (1947), importante recopilación realizada por José María Arguedas y Francisco Izquierdo Ríos. El libro está conformado de narraciones procedentes de la costa, la sierra y la selva, y es un referente para el conocimiento de la memoria oral de los pueblos del Perú. Mediante la lectura de una selección de ellas, el trabajo analiza los principales temas y motivos de la literatura oral, y explica la dimensión mítica y mágica de los personajes y seres imaginarios del universo andino $y$ amazónico. El artículo pone de relieve la temática predominante en los relatos, así como el rol de sus protagonistas en el mundo representado. Desde nuestro punto de vista, la recopilación de Arguedas e Izquierdo Ríos, que es una fuente invalorable para el estudio e investigación del relato popular, constituye una verdadera enciclopedia de la literatura oral y demuestra la enorme riqueza literaria y cultural del Perú.

PALABRAS-CLAVE: literatura oral, motivos tradicionales, mitología andina y amazónica, seres imaginarios 


\section{INTRODUCCIÓN}

El libro Mitos, leyendas y cuentos peruanos (1947) de José María Arguedas y Francisco Izquierdo Ríos es uno de los trabajos recopilatorios de notable importancia de la literatura oral en el Perú. Ambos, conocidos escritores y estudiosos de la literatura andina y amazónica, respectivamente, realizaron una de las mayores contribuciones en la conformación de un corpus representativo de la memoria oral de los pueblos del Perú. A pesar del tiempo transcurrido y de la publicación de valiosos estudios, antologías y nuevas recopilaciones realizadas en la segunda mitad del siglo XX y en el curso de la presente centuria, el libro de Arguedas e Izquierdo Ríos continúa siendo un referente de obligada consulta para el estudio, conocimiento e investigación de la literatura oral en el Perú.

Mediante la lectura de una selección de narraciones que conforman el libro, el propósito de este trabajo es estudiar determinados temas y motivos desarrollados en ellas, así como explicar la dimensión mítica y mágica de los principales personajes y seres imaginarios del universo andino y amazónico que figuran en sus páginas. En ese sentido, las narraciones dan a conocer una diversidad temática de la rica tradición oral: el origen de formaciones de la compleja geografía del territorio peruano, el castigo, las formas que reviste y sus consecuencias, las características y el rol de los personajes de la mitología andina y amazónica, la creencia de que en los cerros y lagunas se halla la madre de la naturaleza, la existencia de seres mágicos y misteriosos, dotados de poderes sobrenaturales y asociados con lugares encantados, y amenos episodios referidos a animales que son protagonistas de relatos de carácter fabulesco.

El artículo subraya el valioso aporte que significó en su momento el trabajo de Arguedas e Izquierdo Ríos y su carácter fundacional como fuente para los estudios de la literatura oral. Al cumplirse en el presente año el cincuentenario del fallecimiento de Arguedas, este trabajo es, también, un homenaje y un reconocimiento a su profunda vocación por conocer, recopilar, difundir y estudiar el patrimonio inmaterial del Perú a través de sus expresiones artísticas y literarias. De esta manera, realzamos el valor del proyecto arguediano de rescatar la tradición oral de las diferentes regiones del Perú, al que consideró el país de todas las sangres, dada su singular riqueza y diversidad cultural.

\section{LA MEMORIA ORAL DEL PERÚ: LA RECOPILACIÓN DE JOSÉ MARÍA ARGUEDAS Y FRANCISCO IZQUIERDO RÍOS}

Publicado en 1947, el libro Mitos, leyendas y cuentos peruanos ${ }^{1}$ recoge un conjunto de narraciones de la costa, la sierra y la selva, y fue posible gracias a la colaboración de alumnos y profesores de colegios nacionales convocados por Arguedas e Izquierdo Ríos para realizar dicho trabajo. Los relatos, basados en las versiones de los informantes, fueron transcritos por los docentes y alumnos, y solo tuvieron mínimas correcciones. Desde el punto de vista formal — salvo algunos textos-, la mayoría de las narraciones son breves, relatan el asunto principal sin mayor complejización estructural y ofrecen una información directa del tema. En su contenido, se observan varias líneas temáticas que desarrollan motivos que forman parte de la literatura oral de los pueblos del Perú, así como motivos pertenecientes a la tradición occidental que se incorporaron al relato folclórico a través de la influencia hispánica. Los seres imaginarios y personajes mitológicos que figuran en los relatos recopilados integran el universo andino y

\footnotetext{
${ }^{1}$ La primera edición fue publicada por el Ministerio de Educación. El libro se encuentra incluido en el tomo 4 de la Obra antropológica de Arguedas (2012). Otras ediciones del libro son las publicadas por las editoriales Santillana (2011) y Siruela (2014). Para efectos del presente trabajo, nos basamos en la edición de Santillana, de donde se toman las citas.
} 
amazónico, algunos de los cuales tienen una procedencia occidental. Las narraciones evidencian la capacidad de adaptación y de reelaboración del imaginario popular que sincretiza la influencia hispánica, la religión cristiana y la cultura occidental, lo que se produce en el marco de un rico y dinámico proceso de transculturación.

Como corpus, Mitos, leyendas y cuentos peruanos es una importante muestra de la literatura oral del Perú en el contexto de la primera mitad del siglo XX y se suma a los trabajos de recuperación de la memoria oral realizados en dicho periodo. Tomando como referencia ese contexto temporal, entre los trabajos de recopilación de la literatura oral y libros de narraciones que recrean temas y motivos de ella, figuran El cóndor y el zorro (2003) de Max Uhle, recopilación que data de 1905 y que se publicó en edición bilingüe alemán-quechua en 1968, Tarmap Pacha-Huaray. Azucenas quechuas (1905) y Tarmapap Pachahuarainin. Fábulas quechuas (1906) de Adolfo Vienrich, Leyendas y tradiciones de Loreto (1918) de Jenaro Herrera, Cuentos peruanos (1937) y Cuentos y leyendas del Perú (1940) de Arturo Jiménez Borja, Mitos, cuentos y tradiciones de Lambayeque (1938) de Augusto León Barandiarán, Literatura inca (1938) de Jorge Basadre y Los cuentos contumacinos del Tío Lino (1939) de Fidel Zárate.

Igualmente, podemos citar Ayahuasca. Mitos. Leyendas y relatos de la Amazonía (1939) de Arturo Burga Freitas, Ande y selva (1939) de Francisco Izquierdo Ríos, Narraciones y leyendas incas (1939) de Luis Eduardo Valcárcel, Folklore de Huancayo (1940) de Emilio Barrantes y Jauja. Estampas de folklore (1940) de Ernesto Bonilla del Valle. A estos títulos debemos agregar el aporte de Arguedas: el libro de cuentos Agua (1935), la recopilación de la tradición poética quechua titulada Canto Kechwa (1938), la revista Pumaccahua (1940), editada por el mismo autor con los trabajos de sus alumnos en Sicuani, y la recopilación Canciones y cuentos del pueblo quechua (1949), algunos de cuyos textos se encuentran en quechua traducidos al castellano.

El énfasis en la temática andina y amazónica se inscribe en el proyecto programático de los escritores de las primeras décadas del siglo XX de revalorar las expresiones populares y locales, lo que, a la vez, se inserta dentro del propósito generacional, impulsado por el indigenismo y el nativismo, de afirmar las manifestaciones artísticas y culturales de los pueblos del Perú. Ello explica el enorme interés que existió entonces por el folclor regional, la música vernacular y la narración oral, así como por el estudio etnográfico del arte, las costumbres, las creencias y las tradiciones de las comunidades de la costa, la sierra y la selva.

Cabe precisar que el libro no reúne el total de narraciones que se recopilaron, pues es solo una selección del vasto material que ambos autores recogieron. Debido al enorme valor de la recopilación, en la actualidad, existe un trabajo de digitalización de dicho material, que demuestra el carácter voluminoso del proyecto y revela la verdadera dimensión del esfuerzo realizado por Arguedas e Izquierdo Ríos. Una selección de estas narraciones fue publicada por el Ministerio de Educación y la Casa de la Literatura peruana con el título Voces nuestras. Cuentos, mitos y leyendas del Perú. Relatos recopilados por docentes (1945-1950) (2012). Dada la envergadura del proyecto inicial, la vasta información obtenida referida a las diferentes regiones y pueblos del Perú, y su intención totalizadora, el libro Mitos, leyendas y cuentos peruanos sienta las bases de una verdadera enciclopedia de la literatura oral y constituye un texto imprescindible para la investigación del relato tradicional.

Además de realizar recopilaciones de la literatura regional, tanto Arguedas como Izquierdo Ríos recrearon en sus cuentos y novelas mitos, leyendas, temas, motivos y episodios protagonizados por personajes míticos de la narración oral. En su obra 
narrativa, Arguedas se nutre de las tradiciones del universo andino, tal como se puede apreciar en sus novelas Yawar fiesta (1941) y Los ríos profundos (1958). Por su parte, la prosa literaria de Izquierdo Ríos se inspira en temas y personajes del mundo amazónico, como nos lo ilustran sus libros de narraciones Cuentos del Tío Doroteo (1950), Los cuentos de Adán Torres (1965) y Sinti el viborero (1967).

La obra creativa de ambos autores fue paralela, igualmente, a una vocación etnográfica que se plasmó en importantes trabajos de investigación de la tradición oral de la sierra y de la selva, respectivamente. Así, Arguedas, como antropólogo y estudioso de las manifestaciones culturales de las comunidades de la sierra, desarrolló interesantes investigaciones sobre el cuento, la poesía, las canciones, las danzas y la música de origen quechua, que se hallan reunidos en su Obra antropológica (2012). Por su parte, Izquierdo Ríos realizó contribuciones relacionadas con el estudio de las tradiciones, las costumbres y la literatura oral de la Amazonía peruana, que se encuentran en las páginas de la Revista Trocha (1941-1942) y en el libro Pueblo y bosque. Folklore amazónico (1975).

\section{JOSÉ MARÍA ARGUEDAS Y EL ESTUDIO DEL CUENTO FOLCLÓRICO}

Arguedas estudia la creación artística, literaria y musical de carácter tradicional en una serie de artículos bajo el título de «¿Qué es el folklore?». En particular, nos brinda una aproximación al estudio del cuento folclórico en tres de ellos: «La literatura oral. El cuento», «Estudio del cuento»y «Estudio de los cuentos. Método de análisis» ${ }^{2}$. En estos trabajos, el escritor y antropólogo analiza el origen, las funciones, la dinámica y las versiones del cuento folclórico. Podemos tomar como referencia sus reflexiones sobre la narración oral, ya que nos ofrecen un marco de lectura para poder comprender y valorar el contenido y el significado de las narraciones recopiladas en Mitos, leyendas y cuentos peruanos.

Para Arguedas, el cuento tradicional forma parte de la literatura oral, modalidad «que se inventa de memoria y no existe otra manera de transmitirla que la de la forma oral» (2012, T. 7: 20). En esa línea, el cuento es creado por el «pueblo iletrado», que, como «no sabe escribir ni leer, inventa relatos, aventuras de seres humanos, de animales, plantas, ríos o montañas y los cuenta, por lo general no a una sola persona sino a un grupo de oyentes» (2012, T. 7: 20). En tal sentido, es importante resaltar el carácter social del cuento, ya que su espacio de recepción es un público colectivo para quien se piensa con una finalidad específica el contenido que desarrolla.

Siguiendo las ideas del autor de Los ríos profundos, el cuento folclórico cumple, en principio, una función moral, social y correctiva. Por otro lado, tiene como propósito dar a conocer la cosmovisión de los pueblos nativos, ya que el contenido del cuento revela una relación con el mito y un vínculo con seres y personajes que conforman el universo local. Desde este punto de vista, el relato oral es un medio que contribuye en la formación y orientación de la conciencia de una comunidad:

El indio inventa un relato para recrear el espíritu de sus oyentes, para ilustrarlos, para exaltar lo bueno y lo bello, para afirmar las reglas o valores morales que rigen la conducta de sus grupos sociales, para infundir temor a los castigos que sufren quienes infringen esas reglas, para explicar el origen de las cosas, para describir las injusticias y demostrar que ellas no quedan impunes, para cimentar en el alma del ser humano la esperanza, para

\footnotetext{
${ }^{2}$ Con el título de «¿Qué es el folklore?», los artículos se publicaron en la Revista Cultura y Pueblo entre 1964 y 1965. «La literatura oral. El cuento» apareció en el n. ${ }^{\circ} 3$ (1964); «Estudio del cuento», en el n. ${ }^{\circ} 4$ (1964); y «Estudio de los cuentos. Método de análisis», en el n. ${ }^{\circ} 6$ (1965). Los textos están incluidos en el tomo 7 de su Obra antropológica (2012), de donde extraemos las citas.
} 
exaltar la imaginación, la fantasía de los oyentes; en fin, para describir el mundo terreno, celeste o social $(2012$, T. 7: 20).

El sentido moral es un objetivo mayor del cuento oral, ya que los temas y motivos que desarrolla poseen un enorme valor «para hacer resaltar las normas, las reglas que se deben respetar para vivir en sociedad o bien para criticar estas normas, para denunciar sus imperfecciones» (2012, T. 7: 44). De este modo, el contenido del cuento folclórico puede avalar el orden imperante, que es necesario mantener, o revelar, por el contrario, sus deficiencias, lo que exige su reformulación. En esa perspectiva, resulta importante la función del cuento en el contexto de la comunidad como guardián de los valores morales y espirituales consagrados por el grupo social. Ello corre paralelo a su poder correctivo, a través del cual busca sancionar los defectos o imperfecciones de la vida humana.

El estudio del cuento provee de una amplia riqueza de información acerca de la forma de ser de los pueblos al antropólogo, el etnólogo o el folclorista, quienes encuentran en él un testimonio directo de la vida de una comunidad y de su cultura. Por ello, el investigador que estudia «las causas que fijan las diferencias de conducta, el modo de ser de cada pueblo, sus rasgos característicos, halla en forma directa y viviente, la descripción de lo que se llama la cultura material y la cultura inmaterial de los grupos sociales» (2012, T. 7: 20).

La dinámica del cuento folclórico nos hace ver el surgimiento de variaciones o versiones que se originan durante su proceso de transmisión. Arguedas explica que el estudio del cuento tradicional permite conocer interesantes formas de reelaboración y de resementización que experimenta el relato oral ${ }^{3}$. Así, en su transmisión, los cuentos suelen incorporar elementos temáticos que no figuran en la versión original, lo que enriquece su contenido:

[...] el relato sufre algunos cambios, pero, sobre todo, cuando alguien de distinta nacionalidad que el hombre que creó el cuento lo recibe, inevitablemente, modificará sus detalles al contrario a su[s] compatriotas o paisanos. El narrador no lo recordará exactamente e incorporará en el relato algunos pasajes de su invención; estos detalles serán tomados, así invariablemente, de la experiencia que tuvo en su propia comunidad; así el cuento sufrirá una especie de «aclimatación», de «adaptación» al nuevo medio en que es difundido (2012, T. 7: 91).

De modo particular, Arguedas demuestra la dinámica del cuento folclórico en su análisis de las variantes que experimenta el cuento El hijo del Oso, procedente de la tradición española, en la narración oral de los pueblos de la sierra del Perú ${ }^{4}$. Mediante este análisis,

\footnotetext{
${ }^{3}$ En Mitologías amerindias, Alejandro Ortiz Rescaniere describe esta peculiar dinámica tomando como referencia el mito y el cuento, que ilustran la organización y composición de los relatos orales americanos: «[...] son muy variados y diferentes entre sí, pero conforman un conjunto. [...] Ciertos temas y formas son comunes o subyacen a relatos de apariencia y tono disímiles. Las combinaciones son múltiples y de distinto tenor. Un argumento puede ser compartido por una serie de relatos, pero cada uno de estos lo desarrollará como una variante o con un propósito distinto. Un mismo asunto puede ser tratado en distintos temas. Un motivo caracteriza un breve episodio de un mito y es una larga secuencia en otro. Hay formas comunes con contenido o propósitos disimiles y viceversa» (2006: 9).

4 Además de ser estudiado por Arguedas, el conocido cuento también fue analizado, entre otros investigadores, por Efraín Morote Best en su libro Aldeas sumergidas. Cultura popular y sociedad en los Andes (1988), Nicole Fourtané en su artículo «Dos versiones peruanas de "Juan (el) Oso"» (Revista de Dialectología y Tradiciones populares, XLV, 1990), Gerald Taylor en su artículo «Juan Puma, el hijo del Oso» (Bulletin de l'Institut français d'etudes andines, vol. 26, n. ${ }^{\circ} 3,1997$ ), Denise Arnold y Ricardo López en su artículo «Jukumarinti sawurinti: El oso-guerrero y la tejedora. Un repertorio literario de lo masculino
} 
el escritor demuestra que los cuentos de origen occidental que ingresan a constituir el repertorio del cuento oral son reconfigurados de acuerdo con la idiosincrasia, los valores, las creencias religiosas y el pensamiento de la comunidad.

\section{EL MOTIVO DEL ORIGEN: LA APARICIÓN DE ISLAS, LAGOS, CERROS, CAÑONES Y ACEQUIAS}

El motivo del origen es una de las líneas temáticas de las narraciones que conforman el libro Mitos, leyendas y cuentos peruanos. Así, estas explican la aparición de islas, lagunas, cerros, ríos, acequias y de otras formaciones de la compleja geografía del Perú. En las narraciones, dicho origen se vincula con la huida de un personaje que busca alejarse de un peligro o no ser alcanzado en una persecución; debido a ello, se produce su conversión en alguna de esas formaciones, motivo que complementa al anterior. También se relaciona con la intervención de un elemento sobrenatural o la acción de una entidad divina que impone un castigo a un acto humano que no muestra respeto por ella o que desafía su poder. En este caso, se conjugan otros motivos como la invasión del espacio sagrado y la desobediencia, lo que conlleva la aplicación de la sanción.

Es muy conocida la leyenda Las islas de Pachacamac, que explica cómo se formaron dichas islas ubicadas al sur de la ciudad de Lima. Las islas son dos, una más grande que la otra. Según la leyenda, la hija de un curaca se había enamorado del hijo de otro curaca. La hija fue recluida por el padre en su palacio y el hijo, mediante un ardid, se convirtió en un hermoso pájaro para poder ingresar a él. La mujer, sin saberlo, introdujo al ave en una jaula y, al poco tiempo, este recuperó su forma humana. La mujer quedó embarazada y tuvo un hijo; el curaca, al darse cuenta del engaño, pidió que mataran a su hija; entonces, esta huye con su hijo y «al voltear la cara, ve con gran sorpresa que la está persiguiendo el mismo pájaro, pero en forma repugnante». En su desesperación, cayó al mar y «el hijo se convirtió en una pequeña isla y ella en una isla grande» (2011: 42) .

La leyenda La Huega trata sobre la aparición de la laguna del mismo nombre, situada a pocos kilómetros de la ciudad de Ica, al sur de Lima. Según la narración, una mujer muy bella de largos cabellos rubios solía permanecer sola sentada cerca de unos cerros mirándose siempre en un espejo. En cierta oportunidad, al ser abordada por un forastero que fue hacia ella «para preguntarle el motivo por el cual se encontraba tan sola en esos lugares», la mujer huyó de él y en su huida «se le cayó el espejo que tenía, y del espejo se formó la laguna de la Huega» (2011: 47).

Un relato muy popular del pueblo de Caravelí, ubicado en el departamento de Arequipa, denominado La pampa del Indio Viejo cuenta el origen de tres cerros que tienen una forma humana. Este relato desarrolla otro motivo de la narración oral referido a la invasión del espacio sagrado que solo le pertenece a la divinidad local, por lo que su acceso está prohibido, más aún si en dicho lugar existen riquezas que son objeto de codicia. El núcleo narrativo principal del relato es el castigo debido a la ambición que impulsa al hombre a transgredir el recinto sagrado de los apus.

La narración nos cuenta que tres miembros de una misma familia, el padre, la madre y el hijo, fueron convertidos en cerros de formas diferentes, porque para los apus «se había[n] atrevido a caminar en sus faldas, lo cual era una profanación» (2011: 48). El

y lo femenino en los Andes» (Ciencia y Cultura, n. ${ }^{\circ}$ 9, 2001) y César Itier en su libro El hijo del oso. La literatura oral quechua de la región del Cuzco (2007).

${ }^{5}$ En Dioses y hombres de Huarochirí, se narra también la aparición de las islas de Pachacamac. Según esta versión, Cuniraya Viracocha, un hombre poderoso que tenía la apariencia de menesteroso, estaba enamorado de Cavillaca, doncella muy hermosa. Transformado en pájaro, dejó su semen en un fruto cuyo néctar fue ingerido por ella, quien quedó embarazada y dio a luz a una niña. No aceptando que él fuese el padre de su hija, la doncella fue hacia el mar con la niña y ambas se convirtieron en islas. 
padre fue convertido en cerro cuando estaba chacchando coca; el cerro en que se convirtió la madre «tiene la falda más ancha, porque la mujer se quedó sentada hilando», mientras que el «cerro más pequeño es el indiecito», quien sufrió por la ambición de sus padres. Los lugareños comentan que los cerros braman, «porque se quejan los indios de su terrible castigo» (2011: 48).

La accidentada geografía del Perú se percibe en las abruptas formaciones que existen en sus regiones, entre las cuales se encuentran cañones, abras y pongos. La leyenda El cañón de Atoghuarco, del departamento de Cerro de Pasco, refiere el surgimiento de esta formación. El cañón es descrito como «un lugar sumamente pintoresco; en las noches es tenebroso, los cerros que lo rodean son escarpados y solo crecen allí enredaderas y plantas espinosas» (2011: 79). Su origen se encuentra en la respuesta del apu local a la invocación de una india llamada «la vieja Rucutu», apenada por el maltrato con que los conquistadores se habían ensañado con su hija. Cuenta la leyenda que los invasores ocuparon con sus esclavos las tierras de la india y, pese a su pedido de retirarse del lugar, abrieron caminos en sus sembríos. Peor aún, hirieron a la menor hija de la india, por lo que la madre apeló al espíritu del cerro y le solicitó ayuda «y cuando este maldijo a los malvados extranjeros, el terreno se hundió formando el cañón de Atoghuarco» (2011: 79).

En el relato La acequia encantada, se cuenta la aparición de una enorme acequia que actualmente existe en el pueblo de Orccoccocha, en la sierra de Lima. Los pobladores de dos parcialidades acordaron construir una acequia para irrigar sus tierras, pero, al surgir desavenencias sobre el lugar preciso donde construirla, no se concretó. De pronto, apareció un misterioso hombre montado en un caballo y prometió construirla, pero a cambio de un pedido: «solo yo puedo hacerlo, de la noche a la mañana, si me entregan una doncella» (2011: 85). Concedida una hermosa lugareña, a quien se la llevó rápidamente en su caballo, el extraño hombre cumplió su promesa: «Al día siguiente la acequia estaba lista, bien enlajada con dos túneles por los que corría el agua en abundancia y bordeada por árboles frondosos, los que hasta la fecha existen» (2011: 85). En esta narración, el motivo del origen se desarrolla con otros motivos de la narración oral: la acción benéfica realizada por un ser misterioso aparecido intempestivamente y el sacrificio de una mujer bella.

Camino al pueblo de Celendín, en el departamento de Cajamarca, se observa un muro que tiene la forma de una culebra. Su origen se narra en la leyenda La pampa de la Culebra, según la cual, en tiempos de los Incas, una enorme culebra amenazaba a los pobladores peligrosamente en su destructor avance por el lugar. Su avance solo se detuvo cuando fue fulminado por un rayo: «en sus correrías llegó hasta esta pampa donde, por gracia de Dios, le cayó un rayo y la gran culebra quedó muerta» (2011: 104). Con el tiempo, su cuerpo se cubrió de tierra y polvo, tal como puede divisarse su silueta en la actualidad en la pampa de Celendín 6 .

En la planicie del pueblo de Yupán, en el departamento de Áncash, se encuentra una curiosa formación de piedra que se parece a una mesa. Su surgimiento se relata en la leyenda La mesa del inca. Según esta narración, que se refiere al fin del Imperio del Tahuantisuyo, en dicho lugar, existe «una piedra semejante a una mesa [...] a cuyo alrededor están otras piedras a manera y con características de sillones, destacándose una

\footnotetext{
${ }^{6}$ La pampa de la culebra como último destino de la serpiente también se menciona en la leyenda $L a$ destrucción del pueblo de Tiapollo, de Amazonas. La estrecha cercanía entre Amazonas y Cajamarca explica la mutua interinfluencia cultural entre los pueblos de la selva y la sierra, lo que, a su vez, sustenta la relación temática existente entre las narraciones de la literatura oral de ambos departamentos.
} 
de ellas por su tamaño y forma como el sillón real» (2011: 98). La leyenda nos cuenta que la mesa, los sillones y los ornamentos eran de oro, pero se convirtieron en piedra cuando fue ejecutado el Inca Atahualpa ${ }^{7}$.

\section{EL MOTIVO DEL CASTIGO EN LA NARRACIÓN ORAL: FALTA Y SANCIÓN}

Otra línea temática que se desarrolla en las narraciones recopiladas por Arguedas e Izquierdo Ríos es el motivo del castigo, que se aplica a algún tipo de transgresión. En estos relatos, los seres que cometen dicha falta son transformados en piedras, rocas, cerros, lagunas o serpientes por una fuerza superior o divina. La transgresión presenta varias formas: la rebeldía ante la autoridad, la ruptura del orden moral y familiar, y el faltamiento y la soberbia frente a las divinidades locales. Estas actitudes ponen en tensión el sistema de normas que regulan las relaciones que existen entre los seres humanos y entre estos y los seres superiores, de tal modo que su ruptura trae consigo la imposición de un castigo. En las narraciones, el castigo se reviste de un carácter aleccionador y actúa en un orden moral. Además, tal como lo hemos explicado en la sección anterior, el castigo se articula con los motivos de la conversión y del origen en el plano narrativo.

En El hombre dormido, conocida leyenda de Arequipa, el castigo consiste en la transformación de un guerrero en un cerro por haberse rebelado contra la autoridad del Inca. El guerrero, viéndose perseguido por las fuerzas reales, huyó, pero se quedó dormido en las faldas de una montaña y, por actuar en contra del Inca, fue convertido en cerro «castigado por su padre el Sol, quien sumió al rebelde en un sueño eterno» (2011: $58)$.

La leyenda Pitusira, del departamento del Cusco, refiere la historia de la bella hija del soberbio general incaico Orcco Huaranca, de quien se habían enamorado Sahuasiray y Ritisiray. El general convino en conceder la mano de su hija a quien pudiera llevar agua hasta su propiedad, lo que fue logrado por Sahuasiray al «traer el agua desde las alturas hasta las tierras de Orcco Huaranca» (2011: 60). Sin embargo, el día de la boda, la mujer fue en busca de Ritisiray y huyó con él hacia la cordillera, donde «Dios quiso castigarlos y convirtió a Pitusira en un monolito de piedra junto con su amado Ritisiray» (2011: 60). En esta trágica historia, el amor de la hija desconoce la autoridad del padre, la desafía y genera la respuesta divina.

En el mismo significado moral del texto anterior, se inscribe la narración El cerro de Oyocco, de la tradición oral del departamento de Huancavelica. En este relato, son castigados dos jóvenes, hijos de una humilde campesina, quienes, por desobedientes y ociosos, no cumplieron con los reiterados pedidos de la madre de sembrar semillas de maíz en la chacra familiar. Por el contrario, los hijos exigían a la madre mayor atención a sus antojos con la comida y, ante tanta insolencia, «de repente, se produjo un fuerte viento, con una gran polvareda rojiza, que sacó a aquellos de la casa y los estrelló en el cerro Oyocco, donde actualmente se ven las figuras de dos caras humanas» (2011: 70).

\footnotetext{
${ }^{7}$ La referencia a hechos, episodios y personajes relacionados con la historia del Imperio de los Incas figura en diversas narraciones de la tradición oral peruana. La muerte del Inca Atahualpa es un asunto que se recrea en piezas teatrales y la danza de los pueblos de la sierra. Además de la conversión de los metales preciosos en piedra o su desaparición, otro motivo que se desarrolla en las narraciones recopiladas por Arguedas e Izquierdo Ríos es el ocultamiento bajo tierra o en lugares inaccesibles de tesoros que eran objeto de codicia. Las leyendas El pueblo de Narihualá y Yanacocha (del corpus que estudiamos), y Las llamas cargadas de oro (incluida en Voces nuestras. Cuentos, mitos y leyendas del Perú, 2012) desarrollan dichos motivos.
} 
La narración Mama Galla, del pueblo de Huamantanga, ubicado en las alturas de Canta (sierra de Lima), nos cuenta el castigo que recibe una mujer mala por haber asesinado a su hija y pretender hacer daño a sus nietos. La anciana tenía temibles artes «y a todo viajero que pasaba le engañaba con platos y manjares hechos con carne humana» (2011: 82). Cierto día en que no tenía nada que comer, dio muerte a su hija, madre de dos niños, degollándola y bebió su sangre. Los niños, avisados por los trozos de carne de su madre de que debían huir del lugar, empezaron la huida con una ayuda divina: «el arcángel San Miguel les envió una cadena para que pudieran subir por ella» (2011: 83). La anciana, sin embargo, pudo coger un extremo de la cadena, pero esta fue cortada por un pájaro; en su desesperación, próxima a precipitarse al suelo, le pide a un zorro que se tienda para caer sobre él, pero al caer «se convirtió en una laguna y la laguna la ahogó» (2011: 83). Los pobladores cuentan que, en el centro de la laguna, existe una piedra que tiene el nombre de la anciana.

La falta de amor y afecto hacia la madre es objeto de una sanción, tal como se relata en El castigo de una madre, del pueblo de Ocros, en Áncash. La narración se focaliza en la falta de cariño de un hombre hacia su madre; este evita ser visto por ella, se confabula con su esposa para que le mienta a la madre y le diga que no se encuentra su hijo, a quien la progenitora va a visitarla llevándole un poco de carne. Cuando la esposa va a avisarle al marido que su mamá ya se ha marchado, «[c]uál no sería su sorpresa al ver los brazos y piernas del hombre convertidos en serpientes que seguían distintas direcciones» (2011: 90). Como escarnio final, los pobladores quemaron al hombre porque «era castigo de Dios».

En las dos narraciones anteriores, se puede apreciar que la transgresión altera el orden moral y violenta las relaciones establecidas al interior de la vida familiar. Dicha acción merece un castigo ejemplar que la instancia superior impone para poner fin al desequilibrio generado. El castigo se convierte en una acción justa y reparadora que, aun siendo brutal, no resulta desproporcionada, ya que, en el imaginario de las comunidades nativas, se exige la sanción del sujeto transgresor causante de la ruptura del equilibrio moral y espiritual.

El castigo impuesto ante un acto de soberbia se desarrolla en la leyenda El indio de Atun-Irca, del pueblo de Yupán, en Áncash. El protagonista es un indio que, llevado por la ambición, quiso desviar para su provecho personal y el de su familia el curso de dos arroyos que servían de sustento a un poblado ubicado cerca del cerro Crestón. Como sucede en otros relatos, «[e]sta mala intención fue castigada por el dios Sol; de la noche a la mañana, los torrentes desaparecieron con gran sorpresa para el indio y de su familia» (2011: 100). Maldiciendo a los dioses, el indio se arrojó desde la cumbre de un cerro y quedó «convertido en piedra con la cabeza hacia abajo». La suerte de la esposa siguió la misma desgracia, ya que cierto día en que fue a buscarlo subió a la parte alta del cerro y quedó convertida también en piedra ${ }^{8}$.

En las narraciones, el motivo del castigo revela, por otro lado, la furia de la divinidad que reacciona de esta manera debido a una grave falta en que incurre la colectividad. Así, en El pueblo de Huasta, de la literatura oral del departamento de San

\footnotetext{
${ }^{8}$ Las referencias a la conversión de hombres y seres sobrenaturales en piedra se encuentran en narraciones fundacionales del universo andino. En «La leyenda de los hermanos Ayar», que explica el origen del Imperio de los Incas, Ayar Uchu y Ayar Auca quedan convertidos en piedra. En Dioses y hombres de Huarochirí, la serpiente Amaru que lucha contra el dios Pariacaca en defensa del dios Huallallo Carhuincho queda petrificada luego de ser atravesada por el bastón del primero, como también queda convertido en piedra el pájaro llamado cauqui, cuya ala fue usada como lanza por Huallallo Carhuincho.
} 
Martín, se relata el extremo grado de corrupción al que había llegado dicho pueblo «que irritó la cólera divina, resolviendo Dios castigarlo convirtiéndolo en laguna» (2011: 113). La narración revela la influencia de la religión cristiana en la literatura oral, ya que se relaciona con la cólera divina que se describe en diversos pasajes de la Biblia.

La leyenda El origen de la laguna de Pomacochas, del departamento de Amazonas, relata el ejemplar castigo que impone el Taita Amito, el dios local, ante la descomunal soberbia de los habitantes del valle de Pomacochas, quienes se volvieron personas muy ricas por la explotación de la mina de Cullquiyacu. La altanería de los habitantes desafiaba las normas básicas de la ética lugareña y contradecía los principios de reciprocidad y hospitalidad, ya que «[j]amás hacían una obra de caridad, ni menos daban posada a los transeúntes [...] odiaban a muerte a los pobres y no adoraban al Dios verdadero, pues eran idólatras» (2011: 109).

Como castigo, el Dios verdadero envió «una nube blanca que parecía una sábana, y que extendiéndose sobre la ciudad la envolvía por completo [...] las aguas se precipitaron, sepultando en sus entrañas a todos los habitantes» (2011: 110). Como signos de nuevos tiempos, llegó en medio de las aguas la madre de la laguna posada sobre una enorme bandeja de oro y plata, mientras que el Taita Amito llevaba en sus manos «un gran plato lleno de manteca, con peces, plantas de totora, carricillos y cortadera, así como un huevo de pato» (2011: 111). De este huevo, partido por un rayo, salieron aves, los peces se multiplicaron, las plantas empezaron a creer y la vida nuevamente volvió a florecer. La leyenda ilustra el sentido correctivo de la intervención divina en un marco de resonancias míticas referidas al retorno de la vida y la vuelta a un equilibro inicial luego de ser sancionada la falta.

\section{LA CONVERSIÓN DE LOS HOMBRES EN PÁJAROS O INSECTOS: OTRA CONSECUENCIA DEL CASTIGO}

Entre las narraciones que conforman el libro que estudiamos, existen variantes en el motivo de la conversión: también se presenta como la transformación de las personas que cometen la falta en pájaros o insectos. Además de la intervención de un ser maravilloso o una fuerza sobrenatural, mencionados en la sección anterior, el poder de la brujería también interviene en esta conversión. Las siguientes leyendas, pertenecientes a la literatura oral de Loreto, ejemplifican estas transformaciones, que son, igualmente, consecuencias del castigo.

En la leyenda El paucar, se relata el castigo que recibe un niño que se había malacostumbrado a difundir de manera irresponsable los pormenores de la vida del pueblo. El menor acontecimiento lo propalaba «a los cuatro vientos y en un abrir y cerrar de ojos ya lo sabía la población, y aun solía burlarse de las flaquezas del prójimo» (2011: 150). A pesar de ser convertido en pájaro por un hada madrina de quien se quiso burlar por verla vestida como anciana, el niño no cambió de actitud, pues siguió «propalando las noticias». Después de todo, el castigo surtió un efecto positivo, ya que para los pobladores «cuando canta el paucar es buen augurio, pues está anunciando [...] buenas noticias» (2011: 150).

El castigo a la holgazanería se desarrolla en la leyenda La pinsha. El protagonista es el hijo de una familia hacendosa que «resultó un haragán; odiaba el trabajo y ni se preocupaba por buscar algo para su alimentación» (2011: 153). Cierto día, se burló del tamaño de la nariz de una señora, quien entendía de brujerías y, compadecida de los padecimientos de sus padres, lo convirtió en un pájaro de pico larguísimo como castigo, «condenándolo de esa manera a no poder beber agua, ni de una fuente, ni de un río, sino 
solo de la lluvia, cuando cae del cielo»; por eso, el ave entona su canto «pidiendo agua a Dios» (2011: 153).

La desaparición de un pueblo debido a un cataclismo es un tema recurrente en las narraciones orales. El relato El huncahui cuenta que un pueblo que quedaba junto al lago Cusimayo quedó sepultado bajo sus aguas. Según la narración, de pronto, los náufragos «fueron saliendo uno a uno en forma de pájaros, que comían las hojas de los renacos que crecen en las orillas del lago» (2011: 154). De acuerdo con las creencias del lugar, quien coma los frutos de los renacos queda convertido en el pájaro huancahui. Por ello, los lugareños creen que el canto de esa ave anuncia la muerte.

La conversión en un pájaro es causada también por la propia naturaleza del alma humana, como sucede en la narración La garza blanca. En ese relato, una hacendosa muchacha que «tenía la particularidad de comer cualquier pescado con facilidad» (2011: 154) llegó a ser odiada por sus hermanos, quienes le pidieron a un brujo que la convirtiera en una garza blanca. Según las creencias de la región de Ucayali, esta leyenda explica por qué los lugareños comen con facilidad el pescado: cuando escuchan cantar a la garza, se pasan la saliva del ave por sus fauces para comer sin dificultad la carne de pescado.

La transformación de un hombre de lengua suelta en un animal tiene su variante en El caballito del diablo o chinchilejo, en la que la persona dedicada a difundir historias se convierte en libélula o chinchilejo. El protagonista, un muchacho delgado que, en son de mofa, contaba que provenía del diablo, sentía placer creando intrigas «de tal manera que, en poco tiempo, el tranquilo pueblo se convirtió en un infierno donde imperaban el chisme y la calumnia» (2011: 152). Sin poder soportar más sus chismes, los pobladores acudieron a tres brujos, «quienes después de una serie de oraciones y varios icaros le convidaron un líquido color chocolate y lo convirtieron en un insecto al que le pusieron el nombre de chinchilejo» (2011: 152). Aunque no se ha arrepentido de su charlatanería, ahora, al igual que el paucar, solo anuncia noticias positivas para el pueblo.

\section{PERSONAJES DE LA MITOLOGÍA ANDINA Y AMAZÓNICA EN LA NARRACIÓN ORAL}

Un corpus importante de la tradición oral del Perú tiene como protagonistas a conocidos seres de la mitología andina y amazónica, que se hallan caracterizados por su condición mágica o sobrenatural. En las narraciones recopiladas por Arguedas e Izquierdo Ríos, figuran el amaru, la anciana Achiqueé, el condenado, el pishtaco, el ayaymamam, el Chullachaqui y el yanapuna, que integran la amplia galería de personajes que pertenecen al imaginario de la sierra y la selva. Asociados con diferentes motivos (el origen, el castigo, la errancia del alma, la extracción de la grasa humana, el encantamiento o la protección de la selva), son personajes de numerosos relatos orales.

\section{El amaru}

En la mitología andina, el amaru es una enorme serpiente que alcanza una dimensión divina que se remonta a la época incaica y se relaciona con fenómenos atmosféricos. En las narraciones orales, el hábitat natural del amaru se encuentra en los ríos y lagunas; algunas versiones lo presentan debajo de la tierra, encerrado en medio de una laguna o al interior de un cerro. Estas narraciones describen su temible figura, su tamaño colosal y su gran poder ${ }^{9}$.

\footnotetext{
${ }^{9}$ En su artículo «La serpiente: dimensiones de una divinidad subterránea en los Andes», Francisco Gil (2017) estudia el significado del amaru en el mundo andino, los poderes sobrenaturales que lo caracterizan y su fuerza, que se asocia en una dimensión histórica con la lucha y la rebeldía de los pueblos oprimidos de los Andes.
} 
La recopilación de los escritores citados contiene dos textos centrados en este personaje; el primero desarrolla, entre otros motivos, el rapto de una flor preciada, la desaparición de los bienes, el pecado y el sacrificio expiatorio; el segundo, la rivalidad, la furia de la divinidad local y la aparición de la raza humana sobre la faz de la tierra. Ambas narraciones presentan al amaru como un monstruo maligno que habita en las profundidades de las lagunas; también explican la relación que existe entre el amaru y las aguas en el mundo andino.

En la narración El amaru, procedente de Ayacucho, se relata el sufrimiento y la desolación que viven hombres y animales por haber contravenido el verdadero fin para el que fueron creados. Se creía que se trataba de un castigo como respuesta a su soberbia y por haber caído en el pecado y la ofensa. Todos por igual padecían sed, hambre y desesperación. El castigo había trastocado violentamente el orden de vida en el mundo andino: «La fecunda tierra toda era sin flores ni frutos, pues ni contados granos habían en sus provisiones» (2011: 67). Era tanta la furia que «ni sombra encontraron los cuerpos de hombres y animales que caían sin vida» (2011: 67).

Si bien se admitía que era un castigo divino, sin embargo, la verdadera razón por la cual hombres y animales sufrían era debida al amaru, extraño animal «dotado de vida humana y que vive en el fondo del lago que está junto al pueblo» (2011: 68). Este horrible ser, disfrazado de hombre, se llevó la flor de la escarcha, que es fuente de vida, y la devoró. Esa flor representaba «el bien y la abundancia» y su desaparición explicaba por qué había tanta hambre y desolación. Según la narración, el apu Allakchiri le reveló a un moribundo cóndor que la única forma de rescatar la flor era que un ser puro como ella ingresara a las aguas del lago.

A pesar de los numerosos intentos infructuosos, un pastor venido desde muy lejos pudo lograr la hazaña de arrojarse al lago y rescatar la flor. Mientras se introducía al lago donde estaba el amaru, un espectáculo aterrador empezó a manifestarse: «se agitaron las aguas, moviose con gran violencia la tierra; caían los cerros envueltos en polvo y rodaban con atronador ruido; el viento volaba con fieros crujidos; en fin, todo era rechinar de ira» (2011: 69). Entonces, los hombres prometieron no volver a pecar. Impávidos, los pobladores vieron cómo emergían del lago copos de nube de color blanco (las almas buenas) y negras (las almas malas) que representaban a las personas que se habían arrojado al lago. Solo quedó en el centro del lago el pastor que logró purificar los pecados de los hombres arrojándose al lago. Los copos se convirtieron en lluvia y, desde entonces, «la tierra es verde con flores y frutos». En esta leyenda, se presenta el sacrificio expiatorio en su forma más primigenia, tal como se concebía en la mentalidad india.

En los pueblos del Perú, abundan mitos que tratan sobre la creación del mundo y la aparición del hombre en la tierra. Así, el amaru, descrito como serpiente de figura monstruosa, se asocia en las creencias andinas con el surgimiento de los primeros hombres y es el protagonista del mito La aparición de los seres humanos sobre la Tierra, del departamento de Junín. El relato ubica dicho origen en un tiempo remoto y lo vincula con una lucha entre dos horribles serpientes.

Cuenta esta narración que, en otros tiempos, el valle de Jauja estaba cubierto por un lago, en cuyo centro quedaba un peñón llamado wanka. Este peñón servía de reposo al amaru, pero resultó un espacio insuficiente cuando el arco iris creó un segundo amaru, que, al crecer, necesitaba de dicho peñón. Entonces, empezó una lucha descomunal: los enfrentamientos entre los dos amarus eran tan intensos que, por el extremo de violencia, ambos «se elevaban a grandes alturas en el espacio sobre trombas de agua, agitando el lago» (2011: 54). 
Según el mito, la furia del dios Tikse se desencadenó y «descargó sobre ellos una tempestad, cuyos rayos mataron a ambos, que cayeron deshechos con diluvial lluvia sobre el ya agitado lago, aumentado su volumen hasta romper sus bordes y vaciarse por el sur» (2011: 54). Formado un valle, salieron del Wari-puquio («wari», 'escondrijo no profanado'; y «puquio», 'manantial') los dos primeros seres humanos conocidos como Mama y Taita, cuya descendencia formaría la raza humana. El amaru se halla «escondido en una cueva» y ha crecido hasta alcanzar una mayor enormidad «y aprovechando los vientos que se forman durante las tempestades intenta escalar al cielo, pero es destrozado por los rayos entre las nubes» (2011: 55). De acuerdo con este mito, una vez castigados los dos amarus por la furia divina, fue posible el surgimiento de los primeros seres humanos provenientes de lugares sagrados.

\section{La anciana Achiqueé}

El origen de los Andes y de la accidentada forma que caracteriza a la geografía andina se explica en el conocido relato El Achiqueé, que se cuenta en varios pueblos de Áncash. Esta narración gira en torno a la huida de dos niños huérfanos de la ansiosa persecución de «una vieja harapienta y muy mala», llamada Achiqueé, que quería comerse a ambas criaturas ${ }^{10}$. Los niños, siguiendo a un pájaro que llevaba en su pico la flor de papa, producto que era muy preciado y escaso en el lugar, llegaron al pueblo de Achiqueé en busca del tubérculo; la mujer vieja «decidió matarlos y luego apoderarse de las papas».

Los niños huyeron de la casa de Achiqueé y, en su huida, son ayudados por varios animales para no caer en las manos de la vieja mala, «a los cuales en agradecimiento les conceden ciertas cualidades que poseen hasta ahora» (2011: 92). Así, el gallinazo por ayudar a las criaturas recibe el don de tener una acertada vista; el puma, quien también se solidariza con los niños, recibe el don de ser el más valiente entre los animales. El único animal que se niega a auxiliarlos es el zorrillo, por lo que la huerfanita le anuncia «que tendrá un olor repugnante y debido a él será atrapado fácilmente por los cazadores » (2011: 92) ${ }^{11}$. En su larga huida, finalmente, los huerfanitos son salvados por San Jerónimo, quien mediante una cuerda los hace subir a un lugar de abundantes papas donde viven muy felices. Los lugareños creen que ese lugar es el pueblo de Arica, donde abunda dicho tubérculo.

La anciana, no obstante, mantiene su empecinada persecución; con engaños, San Jerónimo le lanza una cuerda para que suba, pero esta es roída por un ratoncillo. Achiqueé, al ver que va a caer sobre una roca, lanza una maldición para que su cuerpo «se desparrame», sus huesos «se incrusten en la tierra» y su sangre «seque las plantas y hierbas». Según la leyenda, su caída dio origen a la cadena de los Andes; la escarpada forma de los cerros se debe al horroroso rostro que tenía al momento de caer. Se dice que la sangre de Achiqueé «salpicó»la tierra y, por ello, aparecieron los arenales en la costa ${ }^{12}$.

\footnotetext{
${ }^{10}$ Arguedas ofrece versiones similares en su importante investigación Folklore del Valle del Mantaro, que data del año de 1953 y que se encuentra incluida en el tomo 3 de su Obra antropológica. Con el título de «Cuentos de brujas», reúne tres relatos titulados «Devoradores de niños», en los que interviene la «bruja antropófaga».

${ }^{11}$ El otorgamiento de dones o méritos como agradecimiento por una ayuda y el castigo por obtener una respuesta negativa se desarrollan también en Dioses y hombres de Huarochirí. Cuando Cuniraya persigue a Cavillaca, se encuentra en su camino con varios animales: el cóndor, el puma y el halcón reciben dones, mientras que el zorro es objeto de una maldición.

12 El esquema narrativo de este relato contiene conocidos motivos de la literatura oral andina. La persecución, la intervención de una divinidad cristiana, la cuerda lanzada para ayudar a la víctima, el roído
} 


\section{El condenado}

Según las creencias del mundo andino, el condenado es una persona que ha muerto, pero que vuelve a la vida para pagar sus culpas. Es un conocido personaje de la literatura oral de la sierra del Perú y protagonista de numerosas historias, que revelan la falta o el pecado que le impide descansar en paz. Inscritos en un trasfondo cristiano, los cuentos sobre condenados narran el castigo que sufre el alma al ser rechazados por Dios, lo que los obliga a purgar sus faltas entre los seres vivos ${ }^{13}$. Entre las narraciones recopiladas en el libro, el condenado es el protagonista de un relato procedente de Ayacucho, titulado Ayahuarco, voz quechua que significa «lugar donde se cuelgan los muertos».

La leyenda narra la historia de dos viajeros que iban con mucho dinero, uno de los cuales, por la ambición de quedarse con el dinero del otro, le dio muerte a este. No obstante, el asesino murió misteriosamente en un abismo que existe entre dos cerros ubicados en Ayahuarco, en el pueblo de Huanta. Cuentan los pobladores que ven a «un hombre colgado de una inmensa cadena que sale de ambos cerros; el hombre se lamenta toda la noche y al amanecer desaparece. [...] es aquel que empujó al otro, y que está condenado, y que los diablos lo cuelgan todas las noches» (2011: 63). Este relato, que es una versión de los cuentos sobre condenados, muestra el permanente sufrimiento del asesino: estar atado a una cadena, lamentarse de su acción y ser colgado cada noche por las fuerzas del mal. A diferencia de otros relatos en los que el condenado retorna a la vida para matar, vengarse o salvarse, en esta versión el personaje está sometido a un continuo tormento $^{14}$.

\section{El pishtaco}

Uno de los personajes más temidos del universo andino es el pishtaco, quien se dedica a matar a las personas para extraerles la grasa y la sangre. El pishtaco también es conocido con los nombres de degollador o nakaq en los pueblos de la sierra ( «pishtaco» es una voz de origen quechua que deriva del verbo «pishtay», 'degollar', al igual que «nakaq», que procede de «nakay», con el mismo significado). Numerosas narraciones ofrecen testimonios de su existencia y cruel oficio, como el relato Los pishtacos, que pertenece al pueblo de San Buenaventura, ubicado en la sierra de Lima. Esta historia

o corte de la cuerda, el engaño, la caída hacia la tierra, etc., son episodios que conforman el contenido temático de numerosas narraciones. En el relato Mama Galla, entre cuyos protagonistas figuran también una anciana mala y dos niños, se desarrollan algunos de ellos. De igual modo, con algunas variantes, dichos motivos se encuentran en ciclos narrativos protagonizados por animales del mundo andino.

${ }^{13}$ En la recopilación Cuentos religioso-mágicos quechuas de Lucanamarca, publicada en 1960 e incluida en el tomo 5 de su Obra antropológica, Arguedas analiza la condición del condenado y las razones de su condenamiento; explica el sincretismo y la concepción religiosa que se manifiesta en los cuentos; y estudia el castigo y la justicia indígena que se aplica a los condenados. Sobre la filiación de estas narraciones con cuentos de origen occidental, afirma: «Los cuentos de condenados aparecen en el Perú como unidades originales o integradas a dos cuentos de evidente procedencia europea: "La huida mágica" y "Juan el Oso"» (2012, T. 3: 268).

${ }^{14}$ Sobre esta condición, Nicole Fourtané nos explica: «Algunos relatos nos presentan los terribles tormentos que sufre el condenado en la Cordillera: está sentado al pie del cerro y gime tristemente; está encadenado, desnudo a veces, en medio de la nieve o intenta subir a la cumbre y vuelve a caer constantemente deslizándose» (2015: 120). 
revela la existencia de una práctica violenta y sangrienta en los Andes cuyo origen se remonta a los años de la colonia ${ }^{15}$.

En esta narración, se describe la sanguinaria actividad de los misteriosos personajes que consistía en degollar a personas inocentes, que tenían ciertas características físicas y a quienes sorprendían en su camino. El relato nos dice: «mataban a las personas que salían del campo, especialmente a aquellas que eran gordas y tenían muy buena voz, porque decían que la sangre y la grasa de dichas personas servían en la fundición de las campanas» (2011: 119).

Cuenta la narración que algunos hombres del pueblo fueron en busca de paja a las alturas. Mientras se alimentaban, se acercaron a ellos personas extrañas, quienes les invitaron comida con narcóticos para hacerlos dormir. Sus esposas se dieron cuenta de ello y alertaron a los pobladores, quienes fueron en busca de los campesinos; sin embargo, dos de ellos habían desaparecido. Al llegar a una cueva, se dieron con la terrorífica escena del degollamiento de los dos hombres: «descubrieron los cadáveres de los hombres que faltaban; estaban sin cabeza y colgados de los pies, de unos ganchos asegurados a las rocas que formaban la cueva. En la parte baja había un perol grande donde se depositaba la sangre de los cuerpos yertos» $(2011: 120-121)^{16}$.

\section{El ayamaman}

El relato El Ayamaman, de San Martín, cuenta el origen de un canto muy triste que es entonado por unos pajarillos de la selva. El nombre de las avecillas se deriva de la expresión quechua: «Ayamaman huishchurhuarca», que significa: «Madrecita muerta, nos han abandonado». Es una narración muy difundida en toda la región amazónica, cuyas versiones, incluidas en las principales antologías de la literatura oral de dicha región, no difieren notablemente. El relato revela el misterio que reina en el bosque amazónico, el poder del encantamiento y situaciones dramáticas que afectan a la vida humana, como la orfandad y el abandono.

Las avecillas son, en realidad, dos niños, un varón y una mujer, que fueron abandonados por su padre en plena selva. Según la narración, la mamá de las criaturas había muerto y su papá se había vuelto a casar. La nueva esposa era muy mala y «tenía un odio feroz a los niños, los trataba con el mayor desprecio y los hacía trabajar más de lo que podían resistir sus fuerzas» (2011: 141). Luego de tener un hijo, la esposa le pidió al padre de las dos criaturas que se las llevara a la selva y las abandonara muy lejos. El papá, sumiso y esclavo de su nueva mujer, cumplió con el pedido y, con engaños, llevó a sus hijos al bosque y los abandonó.

Las criaturas, sin embargo, recibieron la protección de los animales y reptiles de la selva, y se sentían reconfortados: «Los niños estaban en la selva como en un palacio encantado. Esta, con sus árboles y animales, los acogió amorosamente. Había algo de sobrenatural en ello» (2011: 142). Pero, para evitar que sufrieran, un hada del bosque los transformó en pajarillos. En esa condición, las dos criaturas se dirigieron a su casa para

${ }^{15}$ El relato sitúa su origen en la época de la República; sin embargo, una detallada investigación de Efraín Morote Best (1988) demuestra que se remonta a los tiempos de la dominación colonial asociado con el empleo curativo de la grasa humana. En las narraciones recogidas sobre pishtacos, se menciona que la grasa extraída sirve para preparar remedios, fundir las campanas para que suenen mejor y hacer funcionar las máquinas.

16 En «Cuentos de Pishtacus (Degollador)», que es una sección de Folklore del Valle del Mantaro, Arguedas ofrece un estudio sobre el sanguinario oficio del pishtaco y precisa que, en los cuentos que recopila, el personaje termina siempre asesinado, al igual como sucede en las narraciones recogidas en el libro Cuentos y leyendas conchucanas de Wilfredo Kapsoli (1993). 
cantar una triste y lastimera melodía y, cuando se les acercó su padre pidiéndoles que regresaran, «ellos volaron a la selva».

\section{El Chullachaqui}

Entre las narraciones referidas a la selva que hemos seleccionado, destacan aquellas cuyo núcleo temático trata acerca del Chullachaqui (del quechua «chulla», 'desigual', y «chaki», 'pie') ${ }^{17}$, el duendecillo de la selva. De acuerdo con las creencias de los pueblos amazónicos, se caracteriza por tener «los pies desiguales»; además, utiliza una serie de recursos para engañar y burlarse de los lugareños que se internan en la selva, quienes, como consecuencia de ello, se desorientan en su camino. Son populares las historias que se refieren a este misterioso personaje del bosque amazónico. Los relatos $E l$ cazador y el Chullachaqui, El Chullachaqui (dos versiones recogidas con el mismo título) y Los chanchitos nos permiten conocer sus características y audacias ${ }^{18}$.

En El cazador y el Chullachaqui, narración de San Martín, se desarrolla la burla de la que es víctima un cazador que se interna en la selva. Luego de oír el graznido de un paujil, fue ingresando a la floresta. Un jabalí de enorme tamaño le llamó la atención y, persiguiendo a la presa, se internó aún más en el bosque. Su objetivo era «sorprender al jabalí en un recodo o detrás de un árbol, para dispararle el tiro que diera término a la batalla» (2011: 168). Sin embargo, se dio con la sorpresa de encontrar las pisadas del Chullachaqui: «la derecha, de pie humano; y la izquierda, de pata de tigre»; de este modo, entendió que «había sido burlado por el diablo de los bosques»: tanto el paujil como el jabalí eran formas de que se valió el Chullachaqui para engañarlo.

Esta misma habilidad del duendecillo para engañar a las personas se puede apreciar en los dos relatos titulados El Chullachaqui, uno procedente de San Martín y otro perteneciente a la tradición oral de Loreto. En el primer relato, mientras una joven mujer pescaba en el riachuelo Cumbaza, se entusiasmó al ver que ingresaba a un paraje muy hermoso rodeado de árboles, que, sin embargo, se fue angostando. En ese instante, se le apareció «un caballero cojo, pero bien vestido, y muy atentamente la invitó a continuar el viaje» (2011: 169). Se trataba de una treta del Chullachaqui, quien, de esa manera, retuvo a la joven en una cueva durante ocho días. La joven pudo librarse del duendecillo después de que un cura bendijera los caminos y los cerros del lugar.

El segundo relato cuenta que dos hermanos se internaron en la selva con sus escopetas para cazar animales. El diablillo de la selva, adoptando la identidad de uno de ellos, acompañó al otro hermano en la faena, pero este, de pronto, notó lo extraño del boscaje y de la frondosidad de los árboles que nunca antes había visto; entonces, se dio cuenta de que «los pies de su acompañante eran desiguales: el pie izquierdo más pequeño y con uñas a manera de garras de tigre» (2011: 172). Haciendo la señal de la cruz e implorando a Dios, el joven logró librarse del Chullachaqui, quien desapareció después de oír la invocación. Al poco rato, pudo volver a reunirse con su verdadero hermano.

\footnotetext{
${ }^{17}$ En las narraciones recopiladas en el libro, varios de los nombres de los personajes, lugares, lagunas y cerros de la selva tienen un origen quechua, lo que se explica por el contacto que establecieron en algún momento de la historia pobladores de la región andina con pueblos de la Amazonía.

${ }^{18}$ En Pueblo y bosque. Folklore amazónico, Izquierdo Ríos describe el aspecto físico y la forma de actuar de este personaje: «[...] justamente el demonio Chullachaqui [...] tiene los pies desiguales, el izquierdo puede ser chiquito como pie de criatura recién nacida [...] como pata de tigre o como una raíz de árbol, mientras que el derecho es de tamaño normal. Las gentes creen ver las huellas de sus pies en el barro de los caminos. El Chullachaqui toma cualquier apariencia, la de un hombre, de un animal, de un árbol, una flor, un arroyo, para engañar y reírse de la gente» (1975: 50).
} 
En Los chanchitos, narración procedente de Loreto, la sorpresa que puede causar el Chullachaqui se relaciona con un hecho «extraordinario»y «fantástico». Cuenta el relato que, mientras se hacía de noche, un hombre se encontró de pronto con «una infinidad de chanchitos muy pequeños, los cuales lo seguían impidiéndole continuar su viaje» (2011: 170). Estos animalitos empezaron a aumentar de tamaño y a adquirir más fuerza a tal punto que cada vez «se volvían más grandes y furiosos», lo que obligaba al hombre a internarse en la profundidad del bosque; entonces, sintió que «era algo misterioso lo que le sucedía». Asustado y desesperado, el hombre solo tuvo como única opción implorar a Dios con mucho fervor para poder salir de allí. Así, de manera repentina, «se encontró en el mismo sitio donde se le aparecieron los chanchitos» (2011: 171). Lo que había presenciado habían sido visiones, que fueron causadas por el terrible duendecillo para confundirlo y dejarlo en medio de la floresta amazónica.

\section{El yanapuna}

En la mitología amazónica, existen animales que tienen un poder sobrenatural que, según los lugareños, estarían dotados de una fuerza que proviene del demonio. El cuento El yanapuma, oriundo de Loreto, trata sobre un puma que vive en la selva y que se halla revestido de poderes especiales, por lo que no puede ser herido ni cazado. El protagonista del relato es José Curinuqui, quien se introduce en la selva premunido de su escopeta para cazar al yanapuna, palabra quechua que se traduce como «tigre negro».

En la narración, resulta infructuoso el acoso de Curinuqui: «sabía que el yanapuna no se dejaba matar, porque muchas veces él y varios cazadores habían visto romperse sus escopetas al dispararle» (2011: 177). A pesar de dispararle tres veces, no logró herirlo; por el contrario, el puma fue detrás de él y, en la persecución, los perros que salían en su defensa eran muertos a dentelladas. Al igual que otros seres de la Amazonía, el yanapuma es un «animal fantástico» que habita en las montañas y encarna la fuerza invencible de la naturaleza. Según los pobladores de la selva, su condición sobrenatural tiene una explicación: «no le entra la bala. [...] es el mismo diablo que se presenta bajo la figura de tigre negro» (2011: 177).

\section{LA MADRE DE LA NATURALEZA EN EL IMAGINARIO POPULAR}

Un eje temático de las narraciones recopiladas en el libro que estudiamos se centra en la creencia de los pueblos de la sierra y la selva en la existencia de la madre de la naturaleza, según la cual hay un animal encantando que se encuentra en las profundidades de una laguna, un cerro o un río ${ }^{19}$. En la mayoría de los relatos del libro, la madre de la naturaleza es el toro, que está revestido de un poder mágico, pero, en las variantes recogidas en el libro, aparecen otros animales, como el cerdo, el burro, el león, el puma y la vaca. De ellos, solamente el puma - llamado el león americano - es oriundo del continente, ya que las demás especies animales llegaron a América durante la época de la conquista española. En ese sentido, es interesante la incorporación y recreación de

${ }^{19}$ Izquierdo Ríos nos explica que «el personaje fabuloso Madre» se asocia con una variedad de seres y personificaciones en la cultura amazónica: «El pueblo cree que las enfermedades, los fenómenos atmosféricos tienen Madre, ser misterioso, animal o con personificación humana, que los origina; así como también algunas cosas, árboles, lugares, ríos, lagos, fuentes, cerros, minas etc., a los que, además, cuida o defiende. En algunos casos la Madre desempeña el papel solo de guardiana» (1975: 52). En la recopilación de Arguedas e Izquierdo Ríos, este extraño ser también es personaje de las leyendas La madre de la viruela y La madre de la mina, ambas de San Martín. 
elementos occidentales en la narración oral, ya que demuestra la interacción entre las culturales locales y la cultura hispánica en el imaginario popular ${ }^{20}$.

La laguna y el cerro son lugares donde abundan riquezas naturales, piedras preciosas y objetos valiosos, que se hallan resguardados por estos animales; estos están revestidos de un poder especial, debido a que se hallan protegidos por los apus o las divinidades locales. La laguna y el cerro constituyen un espacio sagrado que debe ser respetado por los hombres. En algunas narraciones, la madre de la naturaleza se asocia con un ser diabólico, ya que se cree que la criatura le pertenece al demonio. Los relatos refieren que el animal se encuentra dentro de la laguna o en las entrañas del cerro y que, cuando sale a la superficie, causa temor; también nos cuentan que las riquezas existentes en esos lugares despiertan la ambición de las personas de apropiarse de ellas.

En las narraciones, se destaca la condición del toro como un ser encantado, su color oscuro y resplandeciente, y su estrecha relación con objetos preciosos, por lo que es visto como un símbolo de las riquezas naturales. Así, en la narración Curi-Yacu, de un pueblo de San Martín, se relata la existencia de un toro negro y brillante que vive en los arroyos del río Cumbaza. El texto nos dice que el animal «babeaba algo de color amarillo» (2001: 145), que eran pepitas de oro de pura ley. Se trataba de un toro encantado que no dejó rastros cuando desapareció del lugar. Por eso, ese río recibe el nombre de Curi-Yacu, que significa «río de oro». En la leyenda El cerro encantado, del pueblo de Huanta, en Ayacucho, aparece «un toro de oro resplandeciente, que todas las noches baja a beber las aguas del río» (2011: 64). Las aguas son resguardadas por una ninfa muy bella, que impide que el toro agote su caudal. Los pobladores, en su intento de llegar a la cúspide del cerro y capturar al toro, son víctimas de extrañas enfermedades que pueden causarles incluso la muerte.

Otras narraciones describen la furia del toro y su enorme fuerza, lo que puede originar grandes desgracias a los lugareños y que solo acaban cuando el animal es derrotado por la fuerza humana. El relato El toro encantado, también de Huanta, nos presenta dicha furia y los efectos que su poder destructor puede ocasionar a los pueblos de la sierra. Se trata de un toro «negro, hermoso y corpulento, sujeto con una cadena de oro cuyo extremo guarda una anciana de cabellos canos» (2011: 65), que habita en la laguna Rasuhuillca, ubicada en la cima de un cerro. Luego de vencer a la anciana y liberado de ella, el toro hace estallar toda su furia contra la población, con lo que produce el desembalse de la laguna y ocasiona una gran inundación. Dicen los pobladores que el toro fue capturado y hundido nuevamente en la laguna con el temor de que otra vez desencadene su furia destructora. La fuerza descomunal del toro también es vencida en la leyenda La laguna de Shuc, de Amazonas. En esta narración, el personaje Vivian Fonke, conocido brujo de la región amazónica, se enfrenta a un toro negro adoptando la figura de un «toro gato» y logra derrotarlo: «Luego lo condujo al centro de la laguna y hundió las astas de su enemigo en el pantano. Desde entonces la laguna de Shuc dejó de ser mala» (2011: 117).

${ }^{20}$ En las narraciones folclóricas, el toro sustituyó al amaru, lo que explica por qué habita en lugar de él en lagunas o cerros asociados en un tiempo mítico con la enorme serpiente. Al respecto, Arguedas precisa: «El toro impresionó en forma singularmente profunda a los pueblos nativos de América, en especial a los del Imperio Incaico. El indio peruano [...] lo incorporó con extraordinaria totalidad entre los elementos característicos y sustanciales de su cultura» (2011: 183). En el mundo andino, el toro fue inspiración de una rica producción narrativa y artística: «[...] se convirtió en inagotable fuente de leyendas, de supersticiones, de cantos, de nuevas formas de la cerámica y de la escultura popular; en temas de canciones y cuentos; en el más vasto motivo, en el más poderoso incitador de la imaginación popular» (2011: 184). 
Es interesante la narración Los tres toros, contada por los campesinos de Cerro de Pasco, que trata sobre la misteriosa aparición de tres fieras, de extraños colores, que encarnaban a las ánimas del cerro local. De acuerdo con el relato, los comuneros, que necesitaban que su ganado se alimentara de los pastos del cerro Santa Rosa, enfrentaban el peligro que representaba «la feroz embestida de tres enormes toros de filudas astas; uno de color rojo anaranjado, otro blanco nieve y un tercero negro carbón» (2011: 73). Los toros atacaban a los pobladores con tanta furia hasta despedazarlos salvajemente y dejar solo sus huesos. Una aureola de misterio rodeaba la historia de cómo aparecieron las tres fieras en el lugar.

Reunidos los comuneros para lacear a los tres toros y premunidos de sogas, perros, hondas y garrotes, no pudieron capturarlos, ya que, pese a la violenta persecución, sucedía algo inesperado y extraño que solo se podía atribuir a la intervención de una fuerza sobrenatural que protegía a las fieras. Así, el toro rojo, perseguido por los comuneros, en su huida entró en una cueva del cerro y desapareció sin dejar rastro alguno. El toro blanco tampoco pudo ser alcanzado, ya que se fue alejando cada vez más; finalmente, no pudo ser capturado debido a que «habíase desencadenado una tempestad de rayos y granizos que impedían ver al animal» (2011: 75). Se trataba del «pacha suyo», (la «nube de tierra»), que se interponía entre los comuneros y el animal. Finalmente, el toro se internó en una laguna, pues, en esa dirección, se encontraron los rastros que había dejado a su paso.

Un hecho también extraño pone fin a la persecución del toro negro, ya que los captores «fueron sorprendidos por vientos huracanados que hacían caer las piedras de los cerros, apareciendo igualmente una densa humareda negra que se levantaba como de un incendio» (2011: 76). Cuenta la narración que los toros no volvieron a aparecer más y los pobladores pudieron, por fin, llevar a sus animales a alimentarse con el abundante pasto del cerro. De igual modo, al cabo de los años, en los alrededores del lugar, se descubrieron grandes riquezas minerales: «las grandes vetas de oro y cobre en el cerro Santa Rosa, como las de plata de Colquijrca y el carbón de piedra de Goyllar» (2011: 76), lo que se explica porque las tres fieras eran «el ánima de esos fabulosos yacimientos».

La madre de la naturaleza es, en la leyenda Las minas de Cullqui-Yacu, recogida en Amazonas, un burro. Esta narración relata la existencia en el lugar de varias minas de oro y plata que eran explotadas por el ya mencionado brujo Vivian Fonke, quien, sin embargo, no obtenía grandes beneficios como sí sucedía con otro brujo llamado Baboc. El relato nos dice que este brujo tenía un secreto que le permitía usufructuar las riquezas de las minas y «que consistía en saber a qué lado está la madre de la mina, que en forma de burro negro custodia sus tesoros» (2011: 116). La narración ilustra el poder de la mina para defender sus propias riquezas cuando la ambición del hombre quiere apoderarse de ellas. Eso es lo que ocurre con un brujo que tiene mucha codicia y que es devorado por la madre de la mina. Como escarnio, al igual que en otras leyendas, sus huesos fueron colgados de un árbol.

En la leyenda La laguna de Puca-Cucha, también de Amazonas, la madre de la naturaleza es un cerdo. La narración relata el origen de la mencionada laguna, que se forma a partir de la espontánea emanación de agua de un perol abandonado por un agricultor. El agua se volvió un pantano y luego se convirtió en una laguna. El agricultor quiso recuperar su utensilio, pero no lo consiguió, pues apenado «vio asomar por sobre el perol la cabeza de un chancho colorado. Era la madre de la laguna» (2011: 118). Ello explica su denominación: «laguna roja». La narración Un sitio pesado, de la literatura oral de Loreto, hace referencia a esta variante: en un camino de Varaderillo «hay un 
arroyuelo, el que al decir de la gente tiene madre, y salen de allí fantasmas, unas veces en forma de chanchos y otras en la de toros negros, que persiguen a los transeúntes» (2011: 175).

Una peculiar variante en la que el animal que habita dentro de la laguna no es un toro sino un león la hallamos en el relato La laguna de León Cocha, contado por los pobladores de Yauyos, en la sierra de Lima. Se trata de una laguna que se halla rodeada de cerros que antes eran de oro y cuyas riquezas fueron consumidas durante la dominación colonial. En el centro de ella, hay un remolino que deja ver una piedra bien pulida que es «la huella de la pata de un gigantesco león» (2011: 86). Según los habitantes del lugar, de sus aguas sale un enorme felino «que se pone a rugir, y luego desaparece» (2011: 86).

En el relato La laguna de Schururo, procedente de Cajamarca, se dice que la madre de la laguna, según algunos, era un toro y, según otros, un puma, que era de oro. Por su codicia de querer robarse al puma, un hombre es convertido en cóndor como castigo. Sin embargo, su ambición no cesa y, mientras el puma descansaba sobre una piedra tomando sol, el cóndor se lo llevó cogiéndolo con sus garras. Es impresionante el enfrentamiento que se establece entre el cóndor y la laguna, pues esta «se alzó como una columna en persecución del cóndor y se entabló entre ambos una gran lucha» (2011: 103). Luego de esa tenaz pugna, la laguna venció al cóndor y recuperó a su madre.

La vaca como protagonista en lugar del toro aparece en la leyenda La vaca que arrojaba fuego, perteneciente al pueblo de la Calzada, en San Martín. La narración nos refiere que, camino a Moyobamba, solía aparecer «una fiera, con aspecto de vaca, con largos cachos retorcidos, que arrojaba fuego por la boca» (2001: 138). Llamada VacaHuillca (que significa «vaca sagrada»), amenazaba con destruir al pueblo, pero fue vencida gracias a las prácticas de un brujo. Desde entonces, se considera que la fiera se halla en la laguna de Cochaconga.

\section{FANTASMAS, ESPÍRITUS Y SERES MISTERIOSOS Y FANTÁSTICOS: UN UNIVERSO MARAVILLOSO}

Seres misteriosos y fantásticos habitan el universo andino y amazónico. En ellos, se pone de manifiesto una serie de supersticiones y creencias populares que revelan la fuerza de la naturaleza y el misterio de los lugares encantados. Entre estos seres, se encuentran la lamparilla, caracterizada por su luminosidad; los espíritus del río, que protegen sus aguas; los espíritus del bosque, que desorientan a quienes se internan en la selva; el espíritu del árbol catahua, de propiedades curativas; seres fantásticos que existen en las profundidades de los ríos y lagunas, como la sirena y el yacuruna; la mujer bella con poderes sobrenaturales, que emerge de las aguas; personajes conocidos como «las duendes», de la selva amazónica; las brujas, caracterizadas por su maldad; y el basilisco, temible serpiente de poder destructor.

Es creencia común en los pueblos de la selva la existencia de un fantasma luminoso que tiene la figura de un esqueleto y que lleva a la altura del corazón una intensa luz. Es posible que su origen se relacione con los insectos de luz que abundan en la región amazónica. En el relato La Lamparilla, de San Martín, se refiere la lucha que sostuvo un lugareño de Juanjui con dicho fantasma, que solía asustar a las personas que transitaban durante las noches. En cierta oportunidad, el hombre desafió al fantasma y le asestó una dura golpiza «viendo como consecuencia caer a la Lamparilla y desaparecer la luz» (2011: 163). Al prender un fósforo, solo encontró en el suelo un insecto y «comenzó a despedazarlo con la punta de la caña, pero antes de que terminara su tarea se apagó el 
fósforo, y cuando prendió otro ya no encontró al insecto muerto; había desaparecido» (2011: 163).

En la narración Los baños de Piquilhuanca, oriunda de Cerro de Pasco, se describen los conocidos baños situados en el cañón de Atoghuarco. Esta fuente de aguas termales nace del lago que habita en el interior de los cerros aledaños; según los pobladores, dos espíritus protegen sus aguas: uno de ellos es el espíritu del río, a quien se le suele ver volando, parece un sapo con alas y, a veces, se vuelve un murciélago; el segundo es el espíritu de la fuente, una bella mujer que se arregla el cabello con un peine de oro. Se cree que «todas las tardes y todas las mañanas, los espíritus se bañan en Piquilhuanca y que ese es el motivo de sus virtudes curativas» (2011: 77).

Los espíritus del bosque pululan en el mundo amazónico y asustan a las personas que se internan dentro de él. Ese episodio se relata en El campisto y el Ángel Caído, de la Amazonía. En la floresta, se encontraba un campesino que se había guarecido debajo de un árbol para pasar la noche: «El bosque se inundó de una oscuridad terrible, y ruidos extraños no lo dejaron dormir [...] a medianoche escuchó que alguien cantaba; después oyó una carcajada» (2011: 127). Entonces, fue sorprendido por un espíritu del bosque conocido como el Ángel Caído, que fue tras él con otros espíritus para arrastrarlo hacia las entrañas de la floresta. Grande fue la sorpresa de estos malos espíritus cuando brotó un gallito de un huevo que el campesino llevaba como único alimento; entonces, este cantó: «Ya amaneció» y los espíritus, asustados por la llegada de la luz del Sol, huyeron a sus cavernas. No obstante, no conformes con lo sucedido, le advirtieron: «Agradece que ya es de mañana. Pero otro día nos la pagarás» (2011: 127).

Para los habitantes de la selva, existe un ser fantástico que se halla consustanciado con el bosque y se distingue por poseer poderes sobrenaturales. En El Sacha Runa («gente del monte»), perteneciente a la narración oral de Loreto, se relata la forma como este ser fantástico obstaculiza la labor del cazador que ingresa a la selva. El misterioso ser produce extraños ruidos, hace aparecer visiones de animales con el fin de que conduzcan al cazador al centro de la selva y se desoriente: «Si el cazador sale sin novedad de estas pruebas y otras más, el Sacha Runa hace caer una terrible tempestad [...] hasta obligarlo a regresar a su casa, sin cazar un solo animal, pues por más que dispare contra uno de estos, no acierta a alcanzarle» (2011: 174). De esta manera, el cazador queda «shingureado», es decir, no logra realizar su objetivo.

El relato La madre de la catahua, también de Loreto, tiene como protagonista a un hombre negro, extraño, de diminuta estatura. La narración nos dice que, en las noches de Luna clara, «[s]ale desnudo con un sombrero grande, alón, y un palito en la mano» (2011: 172). Se trata del espíritu de la catahua, pues se oculta en ese árbol: «Si alguien lo ve y tose, huye despavorido, llega al espinoso tronco de una catahua y desaparece entre las raíces sobresalientes de este árbol» (2011: 172). De acuerdo con los testimonios de los lugareños, el árbol tiene grandes propiedades medicinales.

Las narraciones de la selva nos cuentan que, en las profundidades de los ríos y lagos amazónicos, existen ciudades, mansiones y palacios llenos de lujo que están habitados por seres fantásticos, tal como se relata en la leyenda La sirena, de Amazonas, y en el cuento El Yacuruna, de Loreto. Según la primera narración, en la laguna de Pomacacochas, vive una sirena con «cabellos largos y rubios adornados con peinetas de oro y piedras preciosas, y unos ojos tan magnéticos, que adormecen a quien los mira» (2011: 124). Con su melodioso canto, anuncia la próxima muerte de algún lugareño y, 
cuando siente simpatía por alguna persona, hace naufragar la nave en que viaja para retenerla en su palacio eternamente ${ }^{21}$.

El segundo relato nos ofrece la historia del indio Fabián Sangama, cuya embarcación, que navegaba sobre las aguas del río Huallaga, se vio, de pronto, sumergida en ellas y sus ocupantes se encontraron «en una casa en el fondo del río». La casa tenía techo de arena, había allí «víboras de diferente tamaño y grosor» y «mujeres desnudas y de deslumbrante belleza» (2011: 178). Logrando salir del lugar, Sangama retomó su canoa y enrumbó hacia su destino luego de «haber sido, por breves momentos, huéspedes del Yacuruna» (2011: 178), ser misterioso del universo amazónico que habita en las profundidades de los ríos y cuyo nombre es de origen quechua: «yacu», 'agua', y «runa», 'gente'.

Convertir a las personas en piedra, conocido motivo de la narración oral, es uno de los atributos de la mujer bella que habita en un lugar encantado. Este motivo se desarrolla en la leyenda Los viajeros pachangarinos, del pueblo de Cajatambo, en la sierra de Lima. Esta nos cuenta que dos jóvenes se acercaron a beber agua a las orillas del lago Lacshacocha, donde se hallaba una hermosa mujer que se lavaba los pies: «Los mozos se aproximaron a contemplar la belleza de la joven, y como ella no se diera cuenta, resolvieron tocarla... pero ambos, al momento, se convirtieron en piedra» (2011: 87). En otras narraciones, las víctimas desaparecen conjuntamente con los seres encantados, tal como se relata en la leyenda El pozo encantado, del pueblo de Cañete, al sur de Lima. Su protagonista es una hermosa joven que vive en el interior de un pozo y que suele ofrecer un vaso de agua a quienes se acercan a él. En ese ocasional momento, «el que toma dicha agua desaparece, lo mismo que la joven no quedando ninguna señal de nada» (2011: 46).

Descrito como un lugar maravilloso, la cueva es otro de los escenarios asociados con el encantamiento de la bella joven, tal como se narra en la leyenda La mujer encantada, de Amazonas. Esta nos cuenta que una mujer huérfana de Chachapoyas es llevada a una cueva por un jinete montado en un elegante caballo, quien, supuestamente, era su hermano: «Una vez que llegaron a la cueva el joven desapareció y ella se quedó encantada» (2011: 108). Según la narración, «esta señorita sale en las noches, con su farolito, y llega a las afueras de la ciudad, dicen que en busca de una criatura y un corderito recién nacido con el fin de salvarse del encantamiento»(2011: 108). Exploradores foráneos que llegaron al lugar afirman que, en la cueva, existen muchas riquezas y, en particular, se observa un hermoso salón refulgente de luz donde vive la joven; no se puede acceder a ese luminoso ambiente, porque una laguna de aguas cristalinas no lo permite.

Entre los seres misteriosos del universo amazónico, muy rico y pródigo en historias, figuran «las duendes», cuyo escenario es el bosque. Descritas como «mujeres burlonas que tienen el cuerpo cubierto de pelos gruesos como espinas y que, en las noches, después de las doce, salen a pasear por senderos inaccesibles» (2011: 125), son protagonistas de los relatos Dionisio Ocmata y la duende, y El niño y la duende, de la literatura amazónica. En contraste con su caracterización predominante en el imaginario popular, la primera narración nos presenta a «la duende» como «una mujer blanca de pelos rubios y hermoso aspecto, ricamente vestida y montada sobre un fogoso caballo blanco» (2011: 126). Con dicha apariencia, se presenta ante el leñador Dionisio Ocmata,

${ }^{21}$ Esta leyenda demuestra la influencia de narraciones referidas a seres legendarios de la tradición occidental en la literatura oral del Perú. En la recopilación de Arguedas e Izquierdo Ríos, con el nombre de sirena aparece en la citada leyenda El cerro encantado y en la narración Yanacocha, de Ayacucho, y como ninfa de las aguas en la mencionada leyenda Los baños de Piquilhuanca. En ellas, se describe su belleza física, sus largos cabellos y su canto mágico. 
quien solía ir al monte los domingos, y con su deslumbrante figura lo deja abobado; con engaños, le pide que no la abandone, que no la deje sola: «Y los dos se acostaron en el tambo de Tresleras». En esas circunstancias, el leñador «se quedó profundamente dormido», pero se sintió asombrado con lo sucedido luego de ser despertado por algunos arrieros que pasaban por el lugar.

La segunda narración, sin embargo, ofrece la imagen agreste de «la duende» y la perversa intención de burlarse de su víctima. En este caso, se trata de un niño que es llevado con engaño por ella hacia un lugar de las entrañas de la selva. Mientras iba a buscar leña, el niño pensó ver que se acercaba, supuestamente, su mamá, pero ella «tenía abundante vellosidad». Conducido por ella hacia un chorro de agua para que se bañara, lo dejó desnudo y comiendo estiércol, tal como su verdadera madre lo encontró luego de buscarlo intensamente. Entonces, la madre «[1]o llamó por su nombre y él le contestó dando muestras de locura [...] lo condujo al pueblo, donde lo hizo conjurar» (2011: 128). El niño fue, de esta manera, objeto de burla de «la duende»; peor aún, su madre, al ir a buscar la ropa del hijo que estaba desperdigada entre las plantas y árboles, «oyó una carcajada burlona», con lo que también ella resultó burlada.

La narración Las brujas, de Amazonas, relata la historia de una madre y una hija que eran brujas. Cierto día, la madre le pide a la hija que le consiga una parte del corazón de una persona para calmar su hambre. La hija se convirtió en una lechuza para ir en busca de la víctima, pero solo pudo encontrar al compadre de la bruja. El novio de la chica fue testigo del pedido de la bruja y, sumamente conmovido por lo que había visto y oído, dio aviso al alcalde, quien ordenó «quemar inmediatamente gran cantidad de leña en la plaza y luego ordenó que ataran tanto a la madre como a la hija, de pies y manos, y las arrojaran a las llamas» (2011: 131).

De influencia cristiana e introducida con la llegada de los españoles, la historia del basilisco es el tema de una serie de narraciones orales de la literatura peruana. Una leyenda que se remonta a un tiempo mítico es La destrucción de Tiapollo, un pueblo de Amazonas. El causante de esta destrucción fue el basilisco, extraña serpiente nacida del huevo de un gallo. Criado por una anciana, vivía en un agujero como escondite cerca de una fuente y «[s]iempre que veía una criatura sola delante de la fuente, la atrapaba y devoraba en un instante» (2011: 113). Se convirtió en el pavor de Tiapollo, ya que al crecer salió de su escondite y causó terrible daño a la población: «se hizo presente a los ojos de los que iban a la fuente para proveerse de agua, y los devoraba sin compasión» (2011: 113). Los habitantes huyeron y el pueblo quedó totalmente desierto. El basilisco también devoró a los pobladores de Comacosh, pero fue fulminado por un rayo en Cajamarca, adonde había llegado en busca de más víctimas.

\section{NARRACIONES SOBRE ANIMALES FABULESCOS}

El tipo característico del cuento en el mundo andino y mestizo es el cuento fabulesco que tiene como personajes a animales del universo local y de antigua prosapia en el folclor regional. En sus personajes, se hallan cifrados ciertas actitudes y valores, así como conocidos motivos de la narración oral. En estas narraciones, predominan episodios caracterizados por la burla, el engaño y el castigo, y se revela un sentido didáctico y moral. De la recopilación de Arguedas e Izquierdo Ríos, podemos citar las siguientes narraciones: El zorro y el puma, El sapo de piedra y La carachupita shitarera ${ }^{22}$.

22 En la edición Voces nuestras. Cuentos, mitos y leyendas del Perú. Relatos recopilados por docentes (1945-1950) (2012), se incluyen siete cuentos en la sección «Los burladores burlados», en los que, además 
Uno de los personajes más famosos del cuento folclórico en el Perú es el zorro, caracterizado por su astucia, aunque, algunas veces, es castigado por su soberbia ${ }^{23}$. En $E l$ puma y el zorro, narración de San Martín, el zorro, hábil y astuto, se da cuenta de que el puma ha escondido parte de su banquete, que era un venado cazado por este, entre ramas y hojas secas. El zorro, aprovechando la ausencia del puma, devoró la presa y, luego, se fue a descansar muy orondo; mientras disfrutaba de su siesta, se le acercó el puma haciéndole un cosquilleo con un manojo de hojas. El zorro, entonces, responde con soberbia: «Quítense, quítense moscas, que recién acabo arrebatar su presa al puma» (2011: 161). Y al puma no lo quedó otra alternativa que devorarse al zorro por tamaña osadía. En un plano simbólico, el castigo de la soberbia evidencia el carácter didáctico de la narración.

En otras narraciones, el personaje que recibe el castigo es el sapo, tal como se relata en El sapo de piedra, de Cerro de Pasco. La narración relata la petrificación de un enorme y osado sapo que había ingresado a la casa de una mujer anciana para devorar su cosecha de papas. La anciana, que tenía artes de bruja, lanzó una maldición al sapo: «Acto seguido, oyose un estruendo feroz, se desencadenó una terrible tempestad de viento [...] uno de esos vientos se llevó consigo al sapo [...] hasta que se quedó colgado en lo más alto de una inmensa peña» (2011: 80). La osadía del sapo y la invasión del espacio familiar constituyen una falta que amerita la respectiva sanción, lo cual, a la vez, subraya la lección moral como fin del cuento popular.

En La carachupita shitarera, procedente de San Martín, se desarrolla el engaño reiterado de que es objeto el tigre por parte de una carachupa (armadillo). En las escenas relatadas, el tigre es presentado de manera ingenua, pues obedece inocentemente cada una de las propuestas de la carachupa y termina burlado. Según el relato, luego de pedirle el tigre a la carachupa que le regalara un shitarillo (pececillo de la región amazónica) que había pescado en el río, el armadillo le sugirió que ingresara al río en busca de más shitarillos. Pero el tigre no podía pescar, porque flotaba demasiado; entonces, la carachupa trajo una soga y le «amarró al tigre dos grandes piedras en el pescuezo» (2011: 166). Debido al peso, el felino estuvo a punto de ahogarse y fue en busca de la carachupa para comérsela, mas esta se había subido a un árbol. Desde lo alto, le pidió al tigre que cerrara los ojos para regalarle shitaris: «El tigre hizo lo que le decía su sobrino carachupa y este, en vez de los shitaris, le soltó la piedra y le rompió las muelas» (2011: 166). Fue otra treta del armadillo y nuevamente el tigre quedó burlado.

Continúa el relato con otra estratagema de la carachupa: en un momento en que el armadillo estaba a punto de ser alcanzado por el tigre, le pidió que subiera a un árbol, porque una carta que había leído decía que habría «un diluvio» para los tigres y que él podría salvarse subiéndose al árbol. El ingenio del armadillo no se hizo esperar y, cuando el tigre estaba en la copa del árbol, prendió fuego: «[e]l tigre murió carbonizado y la carachupa regresó al río a pescar de nuevo, tranquilamente» (2011: 166). La reiteración del motivo de la burla ilustra la peculiaridad compositiva del cuento popular, que articula

del zorro, intervienen otros animales del mundo andino. Entre los cuentos, figuran El pericote y la zorra, La zorra y la wachwa, El wáychaw y el zorro y El zorro y la perdiz.

${ }^{23}$ Efraín Morote Best (1988) y Gonzalo Espino (Atuqpacha, 2014) ofrecen un detallado estudio de los diversos motivos que estructuran las variantes de este tipo de narraciones que tienen como personaje central al zorro en la tradición oral andina. Además, en los ciclos narrativos sobre el zorro, este aparece en una relación de rivalidad con el conejo, el cuy, el ratón, la garza, el cóndor y la wáychaw, entre otros personajes. 
su trama combinando episodios típicos que sirven de base a conocidas narraciones orales del mundo andino ${ }^{24}$.

\section{EPÍlOGO}

Las narraciones reunidas en el libro Mitos, leyendas y cuentos peruanos (1947) de José María Arguedas y Francisco Izquierdo Ríos revelan la riqueza temática de la literatura oral en el Perú y el poder mágico de los seres imaginarios del universo andino y amazónico. Conformada por numerosos relatos de la costa, la sierra y la selva, la recopilación nos ilustra el origen de diversas formaciones geográficas de esas regiones, como islas, cerros, lagos, cañones y acequias. En la imaginación popular que sirve de sustento a las narraciones, el surgimiento de tales formaciones se explica debido a un encantamiento, a la sanción de una falta o a la intervención de un poder superior.

El castigo divino es el eje que articula una buena parte de las narraciones de la tradición oral. Inscritas en un orden moral, las narraciones tienen una clara intención de dejar una lección acorde con el fin ejemplar que cumple el cuento tradicional en el seno de una comunidad. De esta manera, la desobediencia, la falta de respeto, la soberbia, la maldad, la corrupción, la ausencia de valores, etc., reciben un castigo que puede convertir al agente transgresor en piedra, pájaro o insecto, como también en un caso extremo este puede concretarse con la desaparición o destrucción de un pueblo.

Los seres del universo andino y amazónico están revestidos de una dimensión mágica y mítica que refleja las creencias de los pueblos del Perú. En ellos, se encarna el poder de la naturaleza, la fuerza del bosque y el misterio de los lugares encantados. En el imaginario de los pobladores, los cerros, las lagunas y los ríos tienen una madre, un animal que adquiere diferentes formas según el relato popular. Fantasmas, duendecillos, espíritus, mujeres bellas, hombres que habitan bajo las aguas de los ríos o lagos, etc., revelan el poder de lo sobrenatural en la imaginación popular. En otra línea narrativa, se encuentran escenas divertidas protagonizadas por animales fabulescos que ponen de manifiesto la riqueza de la narración oral.

Considerando el número de narraciones referidas a las diferentes regiones y pueblos del Perú, así como su temática, motivos, personajes, variantes, versiones, etc., el libro constituye una selección representativa de la memoria oral de dichos lugares. En ese sentido, situándonos en la perspectiva con que Arguedas e Izquierdo Ríos concibieron su proyecto de recopilación, podemos sostener que Mitos, leyendas y cuentos peruanos es una muestra valiosa del intento de construir una verdadera enciclopedia de la literatura oral peruana y una fuente imprescindible e inagotable para el estudio del relato tradicional.

\section{REFERENCIAS BIBLIOGRÁFICAS}

AlcubIERRE, B., BAZÁN, R. Y MIER, R. (Coords.) (2011): Oralidad y escritura. Trazas y trazos, México D. F., Editorial Ítaca.

ARguedAS, José María (2012): Obra antropológica, 7 t. Lima, Horizonte.

\footnotetext{
${ }^{24}$ De modo similar, otros cuentos de la literatura oral se organizan mediante la reiteración de los motivos del engaño, la burla y el castigo. Entre ellos, podemos mencionar El zorro y el león, que tiene al león como personaje burlado; El puma, cuyos protagonistas son un puma y un zorro, quien se burla del primero; $E l$ zorro y el conejo y El ratón y el zorro, en los que el zorro es objeto del engaño.
} 
Arguedas, José María e IZQuiERdo Ríos, Francisco (2012): Voces nuestras. Cuentos, mitos y leyendas del Perú. Relatos recopilados por docentes (1945-1950), Selección de la Comisión Centenario del natalicio de José María Arguedas. Lima, Ministerio de Educación y Casa de la Literatura peruana.

ARguedas, José María e IzQuIERdo Ríos, Francisco (2011 [1947]): Mitos, cuentos y leyendas del Perú, Lima, Santillana.

ÁvILA, Francisco de (2007 [1966]): Dioses y hombres de Huarochirí, 2. a ed. Traducción de José María Arguedas. Lima, Fondo Editorial de la Universidad Antonio Ruiz de Montoya.

BALLÓN, Enrique (2006): Tradición oral peruana. Literaturas ancestrales y populares, 2 t. Lima, Fondo Editorial de la Pontificia Universidad Católica del Perú.

CARranza, Claudia, GutiérRez del Ángel, Arturo y Medina MirAndA, Héctor (Eds.) (2017): La figura de la serpiente en la tradición oral iberoamericana, Fundación Joaquín Díaz, Publicaciones digitales.

ESPINO RELUCÉ, Gonzalo (2014): Atuqpacha. Memoria y tradición oral en los Andes, Lima, Editorial Universitaria de la Universidad Nacional Federico Villarreal.

Fourtané, Nicole (2015): El condenado. Estudio de cuentos peruanos, Lima, Instituto Francés de Estudios Andinos y Centro Bartolomé de Las Casas.

FRENK, Margit et al. (2010): Literatura popular. Simposio sobre literatura popular 2010, Edición digital, Fundación Joaquín Díaz.

GuTIÉRREZ DEL ÁNGEL, Arturo (2017): «La serpiente: dimensiones de una divinidad subterránea en los Andes», en Carranza, Claudia, Gutiérrez del Ángel, Arturo y Medina Miranda, Héctor (Eds.) (2017).

IZQUIERDo Ríos, Francisco (1975): Pueblo y bosque. Folklore amazónico, Lima, Pablo Lorenzo Villanueva.

KAPSOLI, Wilfredo (Comp.) (1993): Cuentos y leyendas conchucanas, Lima, Centro de Información y Desarrollo integral de Autogestión.

LóPEZ Austin, Alfredo y MiLlones, Luis (2016): Los mitos y sus tiempos. Creencias y narraciones de Mesoamérica y los Andes, Cusco, Ceques.

MiLlones, Luis y MAYER, Renata (2012): La fauna sagrada de Huarochirí, Lima, Instituto de Estudios Peruanos e Instituto Francés de Estudios andinos. DOI: https://doi.org/10.4000/books.ifea.6527

MoROTE Best, Efraín (1988): Aldeas sumergidas. Cultura popular y sociedad en los Andes, Cusco, Centro Bartolomé de las Casas.

Ortega, Julio (Ed.) (2012): Nuevos hispanismos. Para una crítica del lenguaje dominante, Madrid, Iberoamericana.

DOI: https://doi.org/10.31819/9783954870172

ORTIZ RESCANIERE, Alejandro (Ed.) (2006): Mitologías amerindias, Madrid, Trotta. 